\title{
Effects of cadmium on metallothionein and histology in gills of tilapia (Oreochromis niloticus) at different salinities
}

\author{
Lisda Nursanti, Eka Nofitasari, Alfiah Hayati, Sucipto Hariyanto, Bambang Irawan and Agoes Soegianto \\ Department of Biology, Faculty of Sciences and Technology, Airlangga University, Surabaya, Indonesia
}

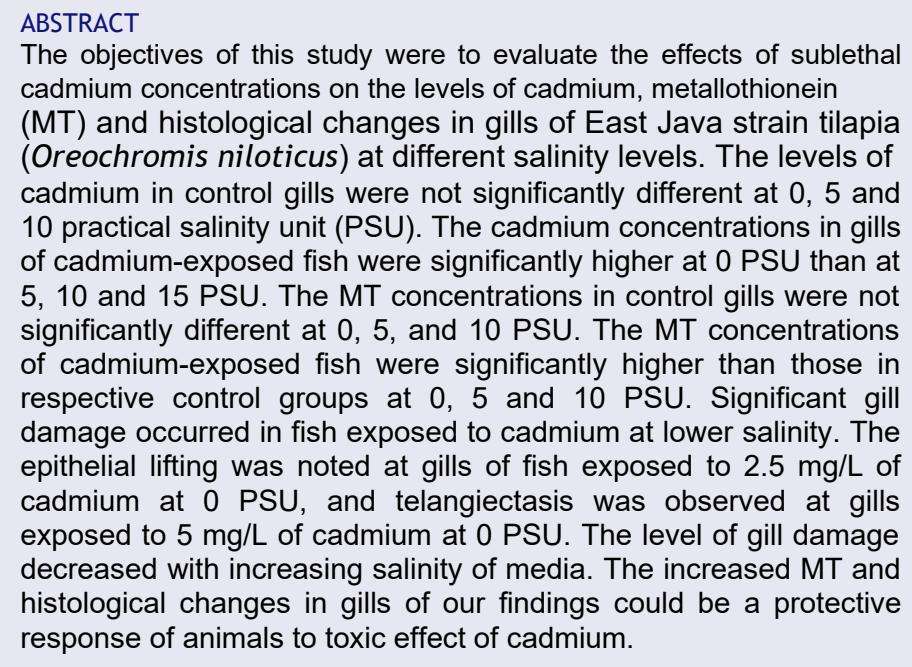

The objectives of this study were to evaluate the effects of sublethal cadmium concentrations on the levels of cadmium, metallothionein (MT) and histological changes in gills of East Java strain tilapia (Oreochromis niloticus) at different salinity levels. The levels of cadmium in control gills were not significantly different at 0,5 and 10 practical salinity unit (PSU). The cadmium concentrations in gills of cadmium-exposed fish were significantly higher at 0 PSU than at 5, 10 and 15 PSU. The MT concentrations in control gills were not significantly different at 0,5 , and 10 PSU. The MT concentrations of cadmium-exposed fish were significantly higher than those in respective control groups at 0,5 and 10 PSU. Significant gill damage occurred in fish exposed to cadmium at lower salinity. The epithelial lifting was noted at gills of fish exposed to $2.5 \mathrm{mg} / \mathrm{L}$ of cadmium at $0 \mathrm{PSU}$, and telangiectasis was observed at gills exposed to $5 \mathrm{mg} / \mathrm{L}$ of cadmium at 0 PSU. The level of gill damage decreased with increasing salinity of media. The increased MT and histological changes in gills of our findings could be a protective response of animals to toxic effect of cadmium.

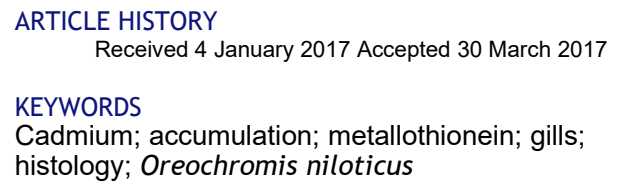

\section{Introduction}

Cadmium is a pollutant that enters the environment from anthropogenic and natural sources. In natural waters, $\mathrm{Cd}$ can occur at concentrations $<0.1 \mathrm{mg} / \mathrm{L}$, but in heavily pol- luted estuaries, it may reach $2-16 \mathrm{mg} / \mathrm{L}$ (Soegianto et al. 1999; Cao et al. 2012). Fish are highly sensitive to Cd contamination (EPA 2001). Exposure to sub-lethal concentrations of $\mathrm{Cd}$ may cause biochemical, osmotic and ionic disturbances, and adaptive responses in blood and tissues (Pelgrom et al. 1995).

Tilapia (Oreochromis niloticus) tolerates a wide range of salinity, and can be cultured in freshwater, brackish water and seawater. Different tilapia strains vary considerably to salinity tolerance from 0 to 32 practical salinity unit (PSU) (Chervinski 1982; Suresh and Lin 1992; Avella, Berhaut, and Bornancin 1993). Baroiller et al. (2000) reported that

O. niloticus did not tolerate salinity above 20 PSU and might not be suitable for culture in full-strength seawater (37-40 PSU).

CONTACT Agoes Soegianto 0 agoes_soegianto@unair.ac.id

(C) 2017 Informa UK Limited, trading as Taylor \& Francis Group 